\title{
Dimension of the upper lateral incisors in hypodontia
}

\author{
Dimensiunea incisivilor laterali superiori în anodonţii
}

\author{
Florina-Maria Mîndoiu, Anca Dragomirescu, Ana-Maria Mihai, Angelica Bencze, \\ Elina Teodorescu, Ecaterina Ionescu \\ Disciplina de Ortodonţie şi Ortopedie Dento-Facială, Facultatea de Medicină Dentară, \\ Universitatea de Medicină şi Farmacie „Carol Davila“, Bucureşti
}

\begin{abstract}
Objectives. To evaluate the upper lateral incisors crown dimensions in pacients with hypodontia and to establish a possible correlation between the hypodontia type and the reduced dimensions of these teeth.

Materials and methods. For this study we examined 52 dental casts of patients with hypodontia (except third molars) who were reffered to the Orthodontics and Dentofacial Ortopaedics Department of the "Carol Davila" University of Medicine and Pharmacy in Bucharest, between 2014 and 2018, divided as follows: 24 casts of patients with one absent tooth, 18 - of patients with 2 congenitally missing teeth and 10 - of patients with 3 or more congenitally miss-ing teeth. The age range for the hypodontia subjects was 8-23 years old, with a mean of 13.76 years. The maximum mesiodistal crown dimensions of the upper lateral incisors were measured on the dental casts with a digital calliper. Statistical evaluation was performed using the Microsoft Office Excel 2016.

Results and discussion. The prevalence of the microdont maxillary lateral incisors was $51.9 \%$. Most of the upper lateral incisors showing morpho-dimensional coronary changes were noticed among female patients $(32.7 \%)$ compared to $19.2 \%$ for the male sex. In the unilateral hypodontia of the upper laterals, the homologous lateral was always found as microdont. As for the patients with 2 congenitally missing teeth, we observed bilaterally microdont upper laterals, both in cases of second mandibular premolars and mandibular central incisors hypodontia. $80 \%$ of dental casts of the subjects with 3 or more congenitally missing teeth had microdont upper lateral incisors.

Conclusions. Patients with hypodontia present a dimensional instability of the upper lateral incisors; the most obvious reductions of the largest mesiodistal diameters were registered in cases with severe hypodontia.
\end{abstract}

Keywords: hypodontia, upper lateral incisor, maximum mesiodistal diameter

\section{REZUMAT}

Obiective. Evaluarea dimensiunilor coronare ale incisivilor laterali superiori în rândul pacienţilor cu anodonţii, precum şi stabilirea unei posibile corelaţii între tipul de anodonţie şi dimensiunea redusă a incisivilor laterali. Material şi metodă. Am analizat un număr de 52 de modele de studiu ale unor pacienţi cu anodonţii (exceptând molarii de minte), care s-au prezentat pentru consultaţie şi tratament de specialitate în cadrul Clinicii de Ortodonţie şi Ortopedie Dento-Facială a U.M.F. „Carol Davila“ din Bucureşti, în perioada 2014-2018, astfel: 24 de modele ale unor pacienţi cu o anodonţie; 18 modele de studiu ale pacienţilor cu câte două anodonţii; 10 modele de studiu aferente pacienţilor cu câte 3 sau mai multe anodonţii. Vârstele dentare ale subiecţilor cu anodonţii ale căror modele au fost analizate au fost cuprinse între 8 şi 23 ani, cu o medie de 13,76 ani. Utilizând un şubler digital, am măsurat diametrele maxime mezio-distale ale incisivilor laterali superiori permanenţi în vederea decelării incisivilor laterali nanici. Înregistrarea şi prelucrarea datelor obţinute a fost efectuată cu ajutorul programului Microsoft Excel 2016.

Rezultate şi discuţii. Prevalenţa incisivilor laterali nanici a fost de 51,9\%. Cei mai mulţi incisivi laterali superiori prezentând modificări morfo-dimensionale la nivel coronar au fost înregistraţi în rândul pacientelor $(32,7 \%)$, comparativ cu sexul masculin $(19,2 \%)$. În cazul anodonţiei unilaterale de incisiv lateral superior, am observat ca incisivul lateral omolog este invariabil nanic. În ceea ce priveşte pacienţii cu câte două anodonţii, am observat incisivi laterali superiori nanici bilateral la nivelul arcadei maxilare, deopotrivă în anodonţiile de premolari doi inferiori şi de incisivi centrali inferiori. $80 \%$ dintre modelele subiecţilor cu 3 sau mai multe anodonţii au prezentat incisivi laterali superiori nanici.

Concluzii. Am putut constata în cazul pacienţilor cu anodonţii ale căror modele de studiu le-am investigat o instabilitate dimensională crescută a incisivilor laterali superiori, cele mai evidente reduceri ale diametrului maxim mezio-distal al acestora fiind întâlnit la subiecţii cu anodonţii extinse.

Cuvinte cheie: anodonţie, incisiv lateral superior, diametru maxim mezio-distal

Corresponding author:

Asist. Univ. Dr. Florina-Maria Mîndoiu

E-mail: florina.trimbitas@yahoo.com
Article History:

Received: 14 May 2019

Accepted: 1 June 2019 


\section{INTRODUCERE}

Anomaliile dentare sunt rezultatul unor interacţiuni complexe între factori genetici, epigenetici şi de mediu care interferă cu procesele de formare şi dezvoltare în perioadele pre- şi postnatală şi constau în alterări ale morfologiei, dimensiunilor, poziţ̧iei sau numărului unitaţilor dentare $(1,2)$. Anodonţia face parte din grupa anomaliilor dentare de număr, acestea caracterizând fie un surplus (dinţi supranumerari) fie un deficit numeric (anodonţia) al formulei dentare normale.

În contextul anomaliilor dentare de număr, anodonţia este anomalia dentară care caracterizează lipsa unităţilor dentare prin neformarea mugurilor dentari, determinând la nivelul aparatului dentomaxilar o multitudine de efecte secundare, prin afectarea funcţiilor fizionomică, masticatorie, fonetică dar şi prin insuficienta dezvoltare a celor două arcade dentare, cu apariţia de malocluzii sau afecţiuni ale parodonţiului marginal, consecutive traumelor ocluzale.

Diagnosticarea precoce a anodonţiilor dimpreună cu implicaţiile clinice pe care această anomalie le poate determina este deosebit de importantă, cu atât mai mult cu cât acestea necesită tratamente de lungă durată, precum şi o colaborăre interdisciplinară - odontoterapie conservatoare, chirurgie oromaxilo-facială, protetică, implantologie (3).

Literatura de specialitate subliniază o serie de modificări sub aspectul dimensiunilor dinţilor, a dezvoltării proceselor alveolare şi scheletale în cazul pacientilor cu anodonţii, mai mult sau mai puţin severe, în corelaţie cu întinderea anodonţiei şi cu tiparul acesteia.

Incisivii laterali nanici, având o prevalenţă între $0,6 \%$ şi $9,9 \%$ în cadrul populaţiei generale (4), constituie una dintre cele mai frecvente manifestări clinice asociate anodonţiei. Cel mai des, incisivii laterali nanici sunt întâlniţi în cazul anodonţiei incisivului lateral superior omolog $(4,5)$ dar şi în cazul anodonţiilor de premolari doi mandibulari (6).

Acest studiu are ca scop evaluarea dimensiunilor coronare maxime mezio-distale ale incisivilor laterali superiori în rândul pacienţilor cu anodonţii.

\section{MATERIAL ŞI METODĂ}

Lotul de studiu a cuprins modelele a 52 de pacienţi cu anodonţie - unică sau multiplă (cu excepţia molarilor de minte) care s-au prezentat pentru consultaţie şi tratament de specialitate în cadrul Clinicii de Ortodonţie şi Ortopedie Dento-Facială a U.M.F. „Carol Davila“" Bucureşti, în perioada 2014-2018, după cum urmează: 24 de pacienţi cu o singură anodonţie; 18 pacienţi cu câte două anodonţii (exceptând anodonţiile bilaterale de incisivi laterali superiori); 10 pacienţi cu câte 3 sau mai multe anodonţii (exceptând anodonţiile bilaterale de incisivi laterali superiori).

Diagnosticul de anodonţie în cazul fiecărui pacient a fost stabilit pe baza dosarului ortodontic care a cuprins: ortopantomogramă, teleradiografie de profil, precum şi fişa pacientului.

Criterii de includere în studiu a modelelor pacienţilor cu anodonţii - modele de studiu iniţiale în stare bună, cu grad minim de atriţie sau uzură dentară ale unor subiecţi care:

- au fost diagnosticaţi cu anodonţia unuia sau mai multor dinţi permanenţi, cu excepţia molarilor de minte;

- nu au beneficiat de tratament ortodontic anterior;

- nu prezentau niciun sindrom genetic.

Metoda de lucru a constat în colectarea datelor din fişele clinice ale pacienţilor, fiind înregistrate următoarele variabile:

- sexul;

- vârsta la data prezentării;

- tipul de anodonţie;

- numărul de dinţi absenţi (cu excepţia molarilor de minte).

Utilizând un şubler digital - calibrat la $0,01 \mathrm{~mm}-$ am măsurat, pe modelele de studiu iniţiale tratamentului ortodontic, diametrul maxim mezio-distal al incisivilor laterali permanenţi decelabili la nivelul arcadei superioare. Conform coordonatelor stabilite de Moorees şi Reed în 1954 - de altfel cel mai des folosite şi acceptate - dimensiunea mezio-distală reprezintă diametrul coronar maxim meziodistal măsurat paralel cu suprafaţa de ocluzie (7).

Toate datele şi valorile măsurătorilor efectuate în cadrul acestui studiu le-am înregistrat şi analizat în cadrul programului Microsoft Office Excel 2016.

La o lună mai târziu de la primele măsuratori am ales, aleator, 15 de modele de studiu în vederea estimării gradului de repetabilitate a tehnicii de măsurare. Astfel, am calculat corelaţia intra-clasă, reprezentând un element de statistică descriptivă ce 
descrie gradul de reproductibilitate a măsurătorilor efectuate pentru acelaşi parametru la intervale diferite de timp. Coeficientul de corelaţie intra-clasă poate avea valori de la 0 la 1 , o valoare apropiată de 0 însemnând că rezultatele măsurătorilor sunt diferite, pe când o valoare apropiată de 1 denotă o corelaţie excelentă între datele analizate.

În cadrul studiului pe care 1-am efectuat, a fost observat un grad ridicat de reproductibilitate a coeficienţilor; media măsurătorilor pentru corelaţia intra-clasă a fost de 0,98 , cu un interval de $95 \%$ de încredere, valorile obţinute fiind 0,97 şi 0,99 , motiv pentru care am considerat că eventualele erori nu se datorează metodei de măsurare (Tabelul 1).

TABELUL 1. Coeficientul de corelație intra-clasă a măsurătorilor efectuate

\begin{tabular}{|l|l|}
\hline Parametru & Coeficientul de corelație intra-clasă \\
\hline $1.2 \mathrm{MD}$ & 0,97 \\
\hline 2.2 MD & 0,99 \\
\hline $\begin{array}{l}\text { 1.2-incisiv lateral superior drept, 2.2-incisiv lateral superior } \\
\text { stâng, MD-diametrul maxim mezio-distal }\end{array}$ \\
\hline
\end{tabular}

\section{REZULTATE}

Vârstele pacienţilor ale căror modele au fost măsurate acoperă o plajă relativ largă, între 8 şi respectiv 23 de ani; vârsta medie a fost de 13,76 ani, majoritatea $(88,5 \%)$ încadrându-se în grupa de vârstă 10-18 ani (Fig. 1).

Numărul modelelor pacienţilor de sex feminin incluşi în studiu a fost de aproape 2 ori mai mare $(65,4 \%)$ decât al celor de sex masculin $(34,6 \%)$, probabil din cauza adresabilităţii crescute şi a disponibilităţii mai mari pentru tratament ortodontic, caracteristice sexului feminin şi poate chiar a frecvenţei mărite a anodonţiilor în rândul acestora (Tabelul 2).
TABELUL 2. Repartiția pacienților în studiu în funcție de sex

\begin{tabular}{|l|c|c|c|c|c|}
\hline & $\begin{array}{c}\mathbf{1} \\
\text { anodonție }\end{array}$ & $\begin{array}{c}\mathbf{2} \\
\text { anodonții }\end{array}$ & $\begin{array}{c}\mathbf{2 +} \\
\text { anodonții }\end{array}$ & Total & Procent \\
\hline $\begin{array}{l}\text { Sex } \\
\text { feminin }\end{array}$ & 21 & 9 & 4 & 34 & $65,4 \%$ \\
\hline $\begin{array}{l}\text { Sex } \\
\text { masculin }\end{array}$ & 3 & 9 & 6 & 18 & $34,6 \%$ \\
\hline
\end{tabular}

Am înregistrat o prevalenţă a incisivilor laterali superiori nanici de 51,9\% (27 de pacienţi) în cazul lotului pe care l-am investigat, cei mai mulţi putând fi observaţi în rândul pacientelor (32,7\%), comparativ cu sexul masculin (19,2\%) (Tabelul 3).

TABELUL 3. Prevalența incisivilor laterali superiori nanici în cadrul lotului studiat

\begin{tabular}{|l|c|c|c|}
\hline & Sex feminin & Sex masculin & Total pacienți (\%) \\
\hline $\mathbf{1 . 2}$ nanic & 6 & 2 & $8(15,4 \%)$ \\
\hline $\mathbf{2 . 2}$ nanic & 5 & 3 & $8(15,4 \%)$ \\
\hline $1.2-\mathbf{2 . 2}$ nanic & 6 & 5 & $11(21,2 \%)$ \\
\hline Total (\%) & $\mathbf{1 7 ( 3 2 , 7 \% )}$ & $\mathbf{1 0 ( 1 9 , 2 \% )}$ & $\mathbf{2 7}(\mathbf{5 1 , 9 \% )}$ \\
\hline
\end{tabular}

În cazul modelelor de studiu ale pacienţilor cu o singură anodonţie, cel mai important aspect remarcat îl reprezintă asocierea anodonţiei de incisiv lateral superior, fie el drept sau stâng, cu talia redusă a omologului său superior. Astfel, în toate cele 9 anodonţii de incisiv lateral superior înregistrate s-au regăsit de dimensiuni mezio-distale micşorate la nivelul incisivilor superiori contralaterali (Tabelul 4).

În ceea ce priveşte pacienţii cu câte două anodonţii, la nivelul modelelor de studiu a 6 pacienţi (din totalul de $18 \mathrm{cu}$ anodonţie dublă) am înregistrat incisivi laterali nanici, cu o distribuţie egală a acestora deopotrivă în cazurile de agenezie a celor doi incisivi centrali mandibulari şi a premolarilor doi inferiori. Important de menţionat este şi faptul că în cazul anodonţiilor ante-menţionate, atât incisivul lateral superior drept, cât şi cel stâng au prezentat diametrul maxim mezio-distal redus (Tabelul 5).

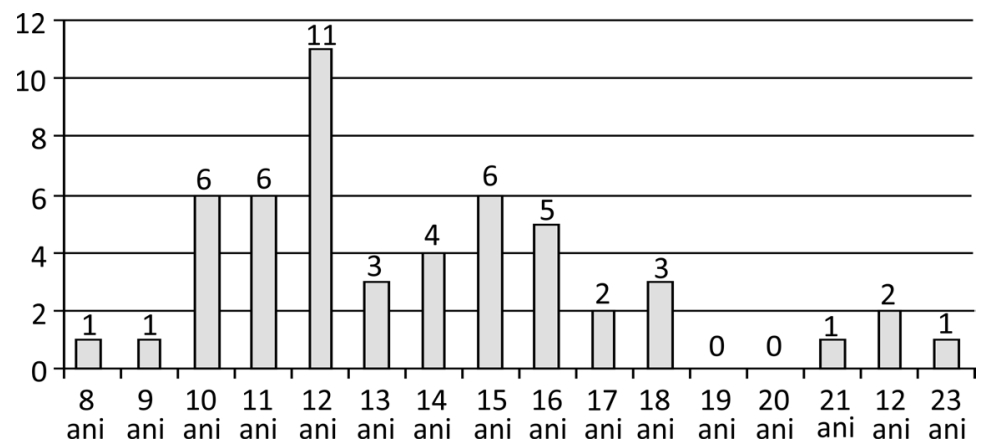

FIGURA 1. Repartiția pacienților din lotul de studiu pe grupe de vârstă 
TABELUL 4. Distribuția incisivilor laterali superiori nanici în rândul pacienților cu anodonție unică

\begin{tabular}{|c|c|c|c|c|}
\hline $\begin{array}{c}\text { Distribuția } \\
\text { anodonțiilor }\end{array}$ & $\begin{array}{c}\text { Număr } \\
\text { pacienți }\end{array}$ & $\begin{array}{c}\text { Număr pacienți cu } \\
\text { incisivi laterali nanici }\end{array}$ & $\begin{array}{c}\text { Număr incisivi laterali } \\
\text { superiori drepți nanici }\end{array}$ & $\begin{array}{c}\text { Număr incisivi laterali } \\
\text { superiori stângi nanici }\end{array}$ \\
\hline $\mathbf{1 . 5}$ & 1 & 0 & 0 & 0 \\
\hline 1.2 & 6 & 6 & $X$ & 6 \\
\hline 2.2 & 3 & 3 & 3 & $X$ \\
\hline $\mathbf{2 . 5}$ & 1 & 0 & 0 & 0 \\
\hline $\mathbf{3 . 5}$ & 3 & 0 & 0 & 0 \\
\hline $\mathbf{3 . 2}$ & 1 & 1 & 1 & 0 \\
\hline $\mathbf{3 . 1}$ & 1 & 0 & 0 & 0 \\
\hline $\mathbf{4 . 1}$ & 1 & 1 & 1 & 1 \\
\hline $\mathbf{4 . 5}$ & 6 & 2 & 2 & 0 \\
\hline $\mathbf{4 . 7}$ & 1 & 1 & 0 & 0 \\
\hline Total & $\mathbf{2 4}$ & $\mathbf{1 4}$ & $\mathbf{7}$ & $\mathbf{7}$ \\
\hline
\end{tabular}

TABELUL 5. Distribuția incisivilor laterali superiori nanici în rândul pacienților cu două anodonții

\begin{tabular}{|c|c|c|c|c|}
\hline $\begin{array}{c}\text { Distribuția } \\
\text { anodonțiilor }\end{array}$ & $\begin{array}{c}\text { Număr } \\
\text { pacienți }\end{array}$ & $\begin{array}{c}\text { Număr pacienți cu } \\
\text { incisivi laterali nanici }\end{array}$ & $\begin{array}{c}\text { Număr incisivi laterali } \\
\text { superiori drepți nanici }\end{array}$ & $\begin{array}{c}\text { Număr incisivi laterali } \\
\text { superiori stângi nanici }\end{array}$ \\
\hline $\mathbf{3 . 1 , 4 . 1}$ & 6 & 3 & 3 & 3 \\
\hline $3.5,4.5$ & 11 & 3 & 3 & 3 \\
\hline $3.1,4.5$ & 1 & 0 & 0 & 0 \\
\hline Total & 18 & 6 & 6 & 6 \\
\hline
\end{tabular}

Cazurile cu anodonţii multiple au prezentat în proporţie de $80 \%$ incisivi laterali nanici, respectiv cea mai mare pondere, raportat la numărul pacienţilor investigaţi în funcţie de întinderea anodonţiei. Am observat ca majoritatea subiecţilor cu trei sau mai multe anodonţii au ambii incisivi laterali superiori nanici. În cazul unui pacient care prezenta şi anodonţie de incisiv lateral superior, am putut remarca, la fel ca şi în cazul anodonţiilor unice de incisivi laterali superiori, talia coronară redusă a contralateralului său (Tabelul 6).

Per ansamblu, din totalul de 96 incisivi laterali superiori măsuraţi am înregistrat un număr de 38 de incisivi laterali nanici, repartizaţi în mod egal la nivelul hemiarcadelor dreaptă şi stângă superioară.

Raportat la tipul de anodonţie căreia i se asociază incisivii laterali nanici, am observat, pentru lotul nostru de studiu, că sunt asociaţi cel mai frecvent

TABELUL 6. Distribuția incisivilor laterali superiori nanici în rândul pacienților cu mai mult de două anodonții

\begin{tabular}{|c|c|c|c|c|}
\hline Distribuția anodonțiilor & $\begin{array}{l}\text { Număr } \\
\text { pacienți }\end{array}$ & $\begin{array}{c}\text { Număr pacienți cu } \\
\text { incisivi laterali nanici }\end{array}$ & $\begin{array}{l}\text { Număr incisivi laterali } \\
\text { superiori drepți nanici }\end{array}$ & $\begin{array}{l}\text { Număr incisivi laterali } \\
\text { superiori stângi nanici }\end{array}$ \\
\hline $1.5,2.5,3.5$ & 2 & 1 & 1 & 0 \\
\hline $1.5,3.5,4.5$ & 1 & 1 & 0 & 1 \\
\hline $2.5,3.5,4.5$ & 1 & 1 & 1 & 1 \\
\hline $3.5,3.1,4.5$ & 1 & 0 & 0 & 0 \\
\hline $1.2,2.5,3.1,4.1$ & 1 & 1 & $x$ & 1 \\
\hline $1.5,2.5,3.5,4.5$ & 1 & 1 & 1 & 1 \\
\hline $1.5,1.4,2.5,3.5,3.1,4.1,4.5$ & 1 & 1 & 1 & 1 \\
\hline $1.7,1.5,1.4,2.4,2.5,3.5,4.4,4.5$ & 1 & 1 & 1 & 1 \\
\hline $1.7,1.6,1.5,1.3,4.3,4.5,4.6,4.7$ & 1 & 1 & 1 & 0 \\
\hline Total & 10 & 8 & 6 & 6 \\
\hline
\end{tabular}

TABELUL 7. Asocierea unor tipuri de anodonții cu incisivii laterali nanici

\begin{tabular}{|l|c|c|c|c|}
\hline \multirow{2}{*}{ Tip anodonție } & \multirow{2}{*}{$\begin{array}{c}\text { Număr } \\
\text { pacienți }\end{array}$} & \multicolumn{2}{|c|}{ Sex } & \multirow{2}{*}{$\begin{array}{c}\text { Procent pacienți cu incisiv lateral } \\
\text { nanici înregistrați în studiu }\end{array}$} \\
\cline { 3 - 4 } & & $\mathbf{F}$ & $\mathbf{M}$ & $33,3 \%$ \\
\hline Anodonție unilaterală de incisiv lateral superior & 9 & 2 & 1 \\
\hline Anodonție uni/bilaterală de premolar 2 inferior & 5 & 4 & 1 & $18,5 \%$ \\
\hline Anodonție uni/bilaterală de incisiv central inferior & 4 & 2 & 2 & $14,8 \%$ \\
\hline
\end{tabular}


anodonţiei omologului lor superior (de pe hemiarcada opusă) - 33\%, apoi lipsei premolarilor secunzi mandibulari $-18,5 \%$, respectiv a incisivilor centrali mandibulari - 14,8\% (Tabelul 7).

\section{DISCUȚII}

Măsurarea diametrelor coronare mezio-distale ale unităţilor dentare, precum şi efectuarea analizei spaţiului total constituie elemente de odontometrie importante şi extrem de utile în procesele de diagnosticare, orientare şi elaborare ale unui plan de tratament (8), cu atât mai mult în cazul pacienţilor cu anodonţii, când provocarea specialistului ortodont este plurifactorială. Astfel, reducerea dimensiunilor dentare - aşa cum se întâmplă şi în cazul incisivilor laterali nanici - face poziţionarea brackeţilor mai dificilă şi determină necesitatea unui ancoraj sporit în cadrul tratamentului ortodontic.

Incisivii laterali nanici sunt frecvent asociaţi cu alte anomalii dentare, cum ar fi: dens invaginatus, canini în palato-poziţie, dinţi supranumerari sau transpoziţii, însă, cel mai frecvent completează tabloul clinic al anodonţiilor (9).

Astfel, Baccetti (6) a remarcat asocierea incisivilor laterali nanici cu anodonţia premolarilor doi; Pinho (4) a sugerat că anodonţia incisivului lateral superior se însoţeşte de microdonţia incisivului lateral omolog. Un studiu meta-analitic privind prevalenţa incisivilor laterali nanici şi conici efectuat de Hua et al. (5) relevă o frecvenţă a acestora de $55,5 \%$ în cazurile cu anodonţie de incisiv contralateral. Garib et al. (10) au observat că în cazul anodonţiei de incisiv lateral superior, cea mai frecventă anomalie asociată este incisivul lateral nanic (38,8\%); Celikoglu et al. (11) au notat o prevalenţă de $45,2 \%$ a incisivilor laterali nanici asociată anodonţiei de incisivi laterali superiori. iar Stamatiou şi Symons (12) au obţinut un procent de 33\% al aceleia şi asocieri.

Rezultatele studiului nostru sunt similare cu cele menţionate anterior. Astfel, am obiectivat la nivelul a 27 de modele de studiu (din totalul de 52) incisivi laterali de talie redusă, iar cea mai mare prevalenţă a acestor incisivi cu morfologie diferită - 33,3\% am observat-o asociată anodonţiei de incisiv lateral omolog.

Asocierea incisivilor laterali conici cu anodonţia de premolari secunzi pe care am înregistrat-o în studiul efectuat $(18,5 \%)$ este în concordanţă cu cele relatate de Baccetti (6), care a studiat tipurile de asociere posibilă între diferite anomalii dentare, printre care şi anodonţia de premolari doi.

În privinţa asocierii anodonţiei de incisivi centrali mandibulari cu prezenţa de incisivi laterali nanici nu am găsit date în literatura de specialitate. De şi lotul pe care l-am studiat este mic, totuşi procentul pe care 1-am înregistrat privind această asociere este destul de mare $(14,8 \%)$, iar din acest punct de vedere considerăm oportună efectuarea unor studii viitoare menite să urmărească o posibilă corelaţie între anodonţia de incisivi centrali mandibulari şi incisivii laterali superiori de talie redusă.

Sub aspectul dismorfismului sexual, am observat preponderenţa incisivilor laterali nanici în rândul pacientelor, asemeni rezultatelor obţinute în majoritatea cercetărilor $(1,5,11,13,14)$.

Alvesalo şi Portin (15), în urma efectuării unui studiu cu privire la etiopatogenia anodonţiei de incisivi laterali superiori, reducerea dimensiunii mezio-distale şi forma lor conică, au concluzionat că anodonţia şi nanicitatea acestora sunt expresii diferite ale aceleiaşi trăsături genetice, spre deosebire de reducerea diametrului mezio-distal, care nu are aceeaşi cauzalitate.

La rândul lor, Stamatiou şi Symons (12) au susţinut că anodonţia incisivilor laterali asociată cu talia redusă a contralateralilor sunt rezultatul afectării unei singure gene care dictează dimensiunea dentară.

Sofaer et al.(16) au propus un model al interactiunilor compensatorii ale dimensiunilor dinţilor. Conform acestor autori, reducerea dimensiunilor dentare, precum şi anodonţia sunt rezultatul unei interacţiuni de compensare între mugurii dentari în timpul proceselor de dezvoltare, absenţa sau talia redusă a unui dinte determinând o creştere a dimensiunii dintelui omolog.

Independent de etiologia incisivilor laterali nanici, conduita terapeutică este cea care are o importanţă majoră, cu atât mai mult în cazurile în care se observă asocierea acestora cu anodonţia incisivului lateral omolog, situaţie în care dezideratele estetice sunt majore.

\section{CONCLUZII}

În cazul anodonţiilor de incisiv lateral superior, de premolari doi inferiori, de incisivi centrali man- 
dibulari sau în anodonţiile multiple cantonate la nivelul ambelor arcade dentare, incisivii laterali superiori nanici au o prevalenţă crescută, determi- nând prin dimensiunea lor mezio-distală redusă afectarea funcţiei fizionomice, a parodonţiului marginal şi o ocluziei dentare.

\section{BIBLIOGRAFIE}

1. Karadas M, Celikoglu M, Akdag MS. Evaluation of tooth number anomalies in a subpopulation of the North-East of Turkey. Eur J Dent. 2014: 8(3); 337-41.

2. Laganà $\mathrm{G}$, Venza N, Borzabadi-Farahani A et al. Dental anomalies: prevalence and associations between them in a large sample of non-orthodontic subjects, a cross-sectional study. BMC Oral Health. $2017 ; 17(1): 62: 1-7$.

3. Ionescu E. Anomaliile dentare. Ed. Cartea Universitară, Bucureşti, 2006.

4. Hua F, He H, Ngan P, Bouzid W. Prevalence of peg-shaped maxillary permanent lateral incisors: A meta-analysis. Am J Orthod Dentofacial Orthop. 2013 Jul;144(1):97-109.

5. Pinho T, Maciel P, Pollmann C. Developmental disturbances associated with agenesis of the permanent maxillary lateral incisor. Br Dent J. 2009;207:E25.

6. Baccetti T. A controlled study of associated dental anomalies. Angle Orthod. 1998;68:267-74.

7. Hillson S, FitzGerald C, Flinn H. Alternative dental measurements: proposals and relationships with other measurements. Am. J. Phys. Anthropol. 2005;126:418-426.

8. Peck S, Peck H. Orthodontic aspects of dental anthropology. Angle Orthod. 1975;45:95-102.

9. Kim JH, Choi NK, Kim SM. A retrospective study of association between peg-shaped maxillary lateral incisors and dental anomalies. J Clin Pediatr Dent. 2017;41(2):150-3.
10. Garib DG, Peck S, Gomes SC. Increased occurrence of dental anomalies associated with second-premolar agenesis. Angle Orthod. 2009;79:436-441.

11. Celikoglu M, Kamak H, Yildirim H, Ceylan I. Investigation of the maxillary lateral incisor agenesis and associated dental anomalies in an orthodontic patient population. Med Oral Patol Oral Cir Bucal. 2012 Nov 1;17 (6):e1068-73.

12. Stamatiou J, Symons AL. Agenesis of the permanent lateral incisor: distribution, number and sites. J Clin Pediatr Dent. 1991;15(4): 244-246.

13. Meskin LH, Gorlin RJ. Agenesis and peg-shaped permanent maxillary lateral incisors. J Dent Res. 1963;42:1476-1479.

14. Polder BJ, Van't Hof MA, Van der Linden FP, Kuijpers-Jagtman AM. A meta-analysis of the prevalence of dental agenesis of permanent teeth. Community Dent Oral Epidemiol. 2004;32:217-26.

15. Alvesalo L, Portin P. The inheritance pattern of missing, peg-shaped, and strongly mesio-distally reduced upper lateral incisors. Acta Odontologica Scandinavica. 1969 Jan 1;27(6):563-75.

16. Sofaer JA, Chung CS, Niswander JD, Runck DW. Developmental interaction, size and agenesis among permanent maxillary incisors. Hum Biol. 1971; 43, 36-45. 